\title{
The Birth and Death of Subjectivity in the Works of William Shakespeare and William S. Burroughs (William And William)
}

\author{
David Frank Allen ${ }^{1}$ \\ Psychoanalyst, Private Practise
}

"For Piers Shore \& Owen Sweet. In death they shall not be divided".

\begin{abstract}
We open with the question of subjectivity as it is presented in Hamlet; the focus then moves to the breakdown of subjectivity as experienced in extreme situations and clinical psychosis. Gabel's idea of continuity from psychosis to ideology (false consciousness) is used to show that William S. Burroughs is in fact a theorist of global ideological pathology. The concept of reification allows us to combine the voices of Gabel and Burroughs. This is not a study of what has been said about Burroughs or Shakespeare, our concern is with the future of the City, not the nature of the finger that points towards it. The cycle of "William \& William" refers to the birth and destruction of subjectivity as defined by "conditions such as these".
\end{abstract}

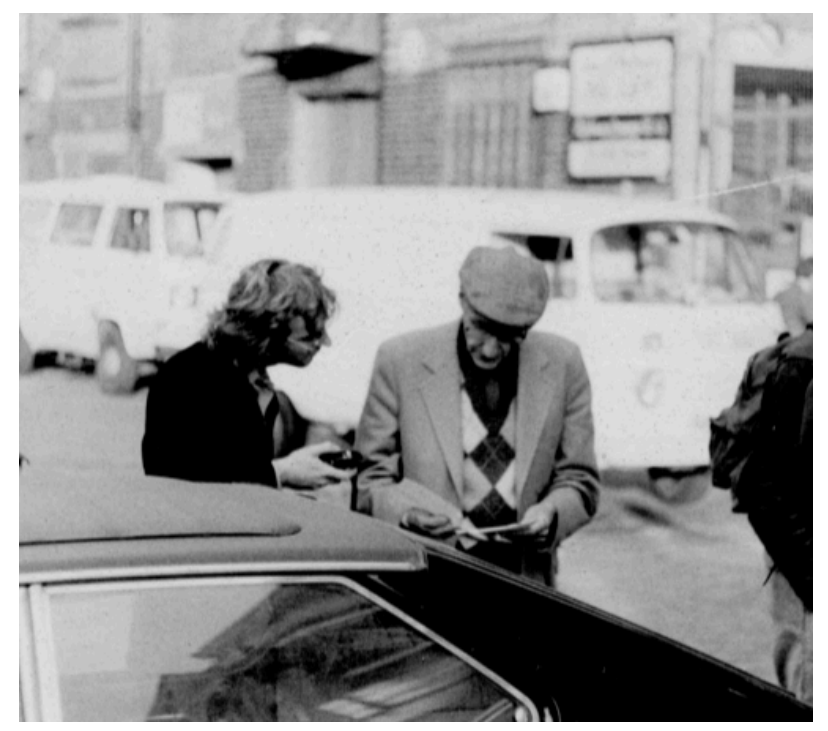

Figure 1

W. S. Burroughs in London for the "Final Academy" in 1982.

${ }^{1}$ Correspondence concerning this article should be addressed to Dr. David Frank Allen, Psychoanalyst, 12 Rue Du Hainaut, 75019, Paris, France. Email: david.allen@uhb.fr

Language and Psychoanalysis, 2018, 7 (1), 35-61.

http://dx.doi.org/10.7565/landp.v7i1.1582 
"I postulate that the function of art and all creative thought is to make us aware of what we know and don't know that we know" (Burroughs, 1979, p. 47).

\section{Introduction}

This article attempts to do several things. First we provide a rapid sketch of Shakepeare's contribution to the nature of the subject and underline his influence on Freud. This introduces the greater part of our work which explores what Burroughs tells us about the end of subjectivity. The concept of reification (Gabel) allows a critical use of a significant part of Burroughs' work and the "algebra of need" is seen as the triumph of the ideology of merchandise and the slow death of selfhood. We are not at all concerned with modern studies of Shakespeare and Burroughs simply because our sole task is to establish a critical outline of future man within the perspectives provided by Burroughs (see Figures 1 and 2), Gabel and others. The reader is thus informed that our concern is not the nature of the hand that points towards the city, it is rather the city itself.

\section{Shakespeare: The Subject as Divided}

Freud began to read Shakespeare early in his life (Michaud, 2011, pp. 32-33) and it would be fair to argue that he provides many solid arguments in favour of a divided subject. The nature of divisions, the way characters live and express their conflicts are expressions of subjectivity. Hamlet, Claudius, Polonius and Macbeth are shoulder deep in conflicts of many shades and hues. Despite this, or rather because of it, there is a clearly stated and well defined sense of self, guilt, choice and decision. As subjects born within filial structures they are in touch with themselves and others, they have a sense of truth and transgression, finally they take decisions as relatively free agents. Even if they have intuitions about the game being rigged and the cards stacked against them their decision are theirs and theirs alone, the 'I' that Burroughs refutes overflows in Hamlet and Macbeth... Shakespeare has a clear theory pertaining to the nature of subject. Division does not prevent the protagonists from defying laws, traditions and perhaps even Gods, on the contrary it is the very architecture of the Self.

\section{Shakespeare's Vision of the Self}

The hypothesis developed here is two-fold: we shall sketch an overview of subjectivity as expressed in Hamlet and Macbeth ${ }^{2}$, in the second part of our study we outline the fall of subjectivity as expressed in the works of William Seward Burroughs. The cycle of the birth and death of subjectivity runs approximately from 1600 to the cold 1950s, we call it "William and William".

Hamlet opens with the essential question "Who's there?" (Nuttal, 1988, pp. 53-69), the play deals with the nature of identity, preconscious and unconscious knowledge, it

${ }^{2}$ The modernity of Macbeth is studied by J. Mervant (2008) in his remarkable Etre ou ne pas être né d'une femme. Macbeth and his Lady return in the BBC version of House of cards. This time round they are in no way hindered by guilt, such is progress.

Language and Psychoanalysis, 2018, 7 (1), 35-61.

http://dx.doi.org/10.7565/landp.v7i1.1582 
asks the question what is a subject? The answers come from many directions; when Hamlet hears that "The serpent that did sting thy father's life now wears his crown" (I.v.39-40) He answers "O, my prophetic soul!" (I.v.41). By this the reader understands that Hamlet already has knowledge or intuition within him about the nature of King Hamlet's death, this well before the message which was imparted by the 'ghost'. Like a good psychoanalyst or a great artist, the ghost makes conscious knowledge Hamlet is already aware of in his soul. The ghost is not the truth per se he is rather the agent or catalyst that reveals truth to he who already knows. One should add that the words of the weird sisters, coupled with those of Lady M. bring Macbeth's ambitions to the foreground, in this sense he is not the sole initiator of his coup d'état.

Claudius is a thug who is bright enough to seduce the boss's wife and get promotion, Hamlet, the prince of equivocation, runs rings round him on several occasions. This should not blind us to the fact that Claudius has a clear theory about a division within language itself. Act III, scene iii: Hamlet has an opportunity to Kill Claudius who is praying to what might be an empty sky. ${ }^{4}$ Hamlet fears that Claudius might go to heaven with a cleansed soul whereas Claudius feels that any appeal to God is inauthentic. In this context of tension and truth Claudius realises that his "words fly up, [his] thoughts remain below. Words without thoughts never to heaven go" (III,iii,97-99). Language is clearly presented in two blocks that may or may not be related, language, Shakespeare argues, exists so that people may lie. The fair and tragic Ophelia also contributes to the question of subjective division, she goes mad for several complex and interwoven reasons. She obeys her father, Polonius, who forbids the relationship with Hamlet for visibly flimsy reasons. Then she is used as a decoy by Polonius, Hamlet sees this as collusion with the enemy. Hamlet's hatred of Gertrude's sexuality fuels his hatred of love and desire. Ophelia pays a high price for the crimes of others. In her madness, close to twilight hysteria, she hits upon a painful truth:

King. How do you pretty lady?

Ophelia. Well, God dild you! $!^{5}$ they say the owl was a Baker's daughter. Lord, we know what we are, but know not what we may be... God be at your table! $(\mathrm{IV}, \mathrm{v}, 45-48)$.

\footnotetext{
${ }^{3}$ According to David and Ben Crystal, Shakespeare's use of the word Soul refers to driving force, animating principle, inner conviction, conscience, heart and inner being... (Crystal, 2002, p. 409).

4 The soul of Claudius is "limed", (III,iii,68) the image stems from birdlime, a sticky substance used to catch birds, the implication is that the King is stuck here on earth. If he clutches to catholic axiology he may hope for hell, if he is limed forever then he simply has nowhere to go.

5 The idea that God should yield or give anything to Claudius is, within the context, dark black irony of the fiercest kind. Claudius cannot find God at his table because he has divorced words from thoughts for all time.
}

Language and Psychoanalysis, 2018, 7 (1), 35-61. 
Ophelia appears to be saying that the subject is aware of identifications in the present, but trauma teaches her that identifications may change or crumble in a state of shock. As her identifications tremble and shake she reveals the secret that binds lovers everywhere:

Ophelia. ... Then up he rose, and donned his clo'es,

And dupped the chamber door,

Let in the maid, that out a maid

Never departed more”. (IV,v,50-54)

The Ghost also contributes to the question of subjective division as does Gertrude ${ }^{6}$ : "O step between her and her fighting soul" (III,iv,114). The ghost's advice is clearly not a tautology, rather it indicates an implicit recognition of subjectivity as built upon different levels of awareness, different fields of knowledge, experience and feeling. There is a space between 'her' and her fighting soul. In other words, 'her' is in no way equivalent to 'her fighting soul', we are obviously dealing with different instances. The Ghost invites Hamlet to occupy this space between so as to soothe Gertrude.

\section{A True Prince of Equivocation...}

Hamlet is in an untenable situation, even before the curtain rises he has lost both his father and his kingdom, the words of the honest ghost push him further, his retreat from the world of appearance allows him to deal with unspeakable truths ${ }^{7}$. He uses equivocation as a form of protective ${ }^{8}$ questioning. Hamlet's puns or quibbles show the subject to be divided by and into different levels of awareness, different ways of hearing words, here are a few clear examples.

6 The Queen states that Hamlet is "Mad as the sea and wind when both contend"(III,iv,7). In 1908 Karl Abraham explained that in hysteria the libido over invested the object, whereas the libido was absent in psychosis (dementia praecox). Freud argued in 1923-1924 that in psychosis (delusions of persecution, paranoia) the subject was at war with the world whereas in neurosis the struggle is a civil war between self and self, between the wind and sea as Gertrude remarks so clearly. See also Abraham's (1908) The psychosexual differences between hysteria and dementia praecox, as well as Freud's Neurosis and Psychosis (1923/1934) and The Loss of Reality in Neurosis and Psychosis (1961).

${ }^{7}$ Regicide, fratricide and, according to Hamlet, incest. Hamlet stands almost alone with the truth and moves in a world of lies and spies, this explains in part his recourse to Ganser type answers to questions. This means that he is acutely aware of the semantic sphere of the question and provides unconventional answers that protect him. His answers are crammed full of meanings even if Polonius and others claim not to understand their drift.

${ }^{8} \mathrm{He}$ is alone with a secret that would bring the kingdom crashing down or else give cause for him to be murdered ...

Language and Psychoanalysis, 2018, 7 (1), 35-61.

http://dx.doi.org/10.7565/landp.v7i1.1582 
Act I, i, 64-65: Claudius makes his first mistake by giving his first attention to Laertes, who is in essence the son of an influence peddler and an obvious hypocrite in sexual terms:

...But now my cousin Hamlet, and my son -

Hamlet. A little more than kin, less than kind.

Claudius makes a second howler by assuming that fatherhood came automatically after a wedding. Hamlet's equivocation spins around the letter 'd'. Claudius is an uncle who claims publicly to be a father - Hamlet warms him off by saying that the connection Claudius lays claim to has no real ground in that the two men do not share the same reality, nature or disposition (Crystal, 2002, p. 251). Hamlet's answer changes the way we hear words and obliges the audience to consider several levels of meaning and different areas of awareness. Claudius continues:

How is it that the clouds still hang on you?

Hamlet. Not so my lord, I am too much in the sun $(\mathrm{I}, \mathrm{i}, 66-7)$.

The equivocation is almost a dagger drawn, Hamlet, whatever the genetics of the question might show, wants nothing to do in filial terms with the head banger who came between his hopes and his election. This stinging pun mirrors the nature of subjectivity in that it is multi-layered: "Hamlet was known...to be alluding to the now obsolete...expression 'Out of heaven's blessing to the warm sun'...the true interpretation of this expression was 'From an exalted, or honourable, state or occupation to a low or ignoble one"" (Wilson, 1935/1995, p. 33) ${ }^{9}$. The second meaning relates to Claudius as "uncle-father" and Gertrude as "aunt-mother" (II,ii,379-380), Claudius claims too much proximity, Hamlet will have none of it. The last aspect of the bitter pun is related to the undeniably melancholy ${ }^{10}$ aspect of Hamlet's nature; the melancholic, according to Dr André du Laurens (1599) is an "enemie to the sun" (Jackson, 1986, p. 87).

Rosencrantz and Guildenstern are not the best of secret agents, along with Polonius they die because of their blind spots. Although he sees through them Hamlet gives them some truth when he declares: "I am but mad north-north west; when the wind is southerly, I know a hawk from a handsaw" (II,ii,382-383). This shows that Hamlet adjusts to the way he is seen by the Other and, in modern clinical terms, he is telling

\footnotetext{
${ }^{9}$ All quotes from Hamlet are from the text established by J. Dover Wilson (1936).

${ }^{10}$ There are several Hamlets, the prince of equivocation dominates the first four acts. On his return, after the pirate story, he has changed, indeed he leaves equivocation to the grave digger. Melancholic Hamlet is painted in colours borrowed from Bright (1586), this should not hide the Hamlet who mourns, grieves and suffers. The roots of Freud's differential study, Mourning and melancholia, are exposed here for all to see. For details regarding Bright's influence on Shakespeare see Wilson (1935/1995, pp. 309-320). For a detailed study of Shakespeare's influence on Freud see Michaud (2011).
}

Language and Psychoanalysis, 2018, 7 (1), 35-61.

http://dx.doi.org/10.7565/landp.v7i1.1582 
us that he does not use clang associations ${ }^{11}$; he is not only consciousness but also consciousness of his specific areas of awareness. His division allows his to include a sense of 'self as seen by Other' alongside the "prophetic soul" of knowledge that cannot yet be shared. The nature of this knowledge encourages Hamlet to declare war on convention and appearances: "...I know not "seems"” (I,ii,76). These four words are as planted seeds...Their significance grows through the play and then through the history of literature.

In Macbeth the divisions are even more violently illustrated: the witches use equivocation to push Macbeth and his kingdom to ruin. Mesmerised, in the truest sense of the word, he sees only the advantages of the witches' words, his wife is divided between a cast iron ambition and an underground sea of guilt that finally overflows in the pre-suicidal fits of sleep-walking. What cannot be said in full daylight manifests itself in nightmares. Repressed feelings may return to the surface Shakespeare suggests. A clearer vision of the self as divided cannot be found. The play illustrates not only the division of the subject but also the way language and suggestion can take hold of a person. Macbeth - along with Polonius, Rosencrantz and Guildenstern - dies because he refuses to hear what is really being said. Our hypothesis is that the Shakespearian theory of the subject, defined by division, lasted roughly until the middle of the 20 th century. The fragmentation of subjectivity was accelerated by the lawlessness ${ }^{12}$ of the second world war, the triumph of merchandise and its algebra of need. What future historians will call "the truthless age "incarnated by the election of George W. Bush, Macron and Trump may well accelerate the decline of the subject and promote externalised awareness defined mainly by merchandise ${ }^{13}$ along with the triumph of forms of jouissance that will no longer be be defined by object relations.

\section{Burroughs towards the $21^{\text {st }}$ century, the end of the I}

On January the 26th 1997, some 8 months before his death, William Burroughs made the following entry into his diary:

I stood in front of the mirror on the landing, in the eerie medium of childhood that withers away and said to the image: 'Three'.

It was my third birthday, and on from there always the feel of something terrible just under the surface... (Burroughs, 2000, p. 69)

On the final page of the chapter 'Astronaut's return' in Exterminator we find:

So many you can't remember

The boy who used to whistle

\footnotetext{
${ }^{11}$ See Hérouard's (1993), Ecrits Inspirés et Langue Fondamentale.

${ }^{12}$ Burroughs suggests that the technology of extermination camps and the the atom bomb foreclosed any idea of 'human law'.

13 "Western man is externalizing himself in the form of gadgets" (Burroughs, 1961/1968, p. 43).

Language and Psychoanalysis, 2018, 7 (1), 35-61.

http://dx.doi.org/10.7565/landp.v7i1.1582
} 
Car accident or was it the war?

Which war?

The boy's room is quite empty now.

Do you begin to see there is no face in the tarnished mirror?" (Burroughs, 1974, p. $27)^{14}$

The first quotation reveals Burroughs' intimate grasp of the mirror phase ${ }^{15}$ (or stage), the point in early childhood in which an external image is internalised so as to form the basis of identification, of selfhood. There is no sense of excitement or triumph here, rather awareness of self is identified as "something terrible just under the surface", as if the great man were born into anguish and a certain degree of ontological insecurity. The second quotation is very close to what French clinicians call 'the mirror sign'; this entails the breakdown of the mirror image that occurs in clinical psychosis; for example, some male patients hallucinate images of a pretty woman and engage in conversations with the hallucinatory image. The patient uses two different voices and sometimes the 'dialogue' ends with bouts of uncontrollable frenetic masturbation. If one opposes the mirror phase to the mirror $\operatorname{sign}^{16}$ a tension between being and non-being is revealed, this tension, as we shall explain, is one of the fault lines to be found in many parts of Burroughs unending œuvre.

The mirror sign, along with the concept of ontological insecurity, allows us to define our second question which concerns the generally unstable, or menacing, relationships between people or 'characters' and bodies in significant parts of Burroughs' work. The question of the disembodied self leads us to our final point; we reject the idea that Burroughs work "set out to defy intelligibility" (Bullock \& Stallybrass, 1977, p. 55) and argue that his legacy is a more than intelligible guidebook of global psychopathology. In this sense Burroughs is one of a small group in which we also find Joseph Gabel author of False Consciousness ${ }^{17}$. What might constitute a meeting place of two thinkers with such clearly contrasting styles and backgrounds? Gabel, who wrote his state thesis under the direction of Eugene Minkowski, uses psychotic thinking as a tool in the analysis of ideological constructs, his genius is to be found in the idea that ordinary people will accept will accept psychotic logic if it is wrapped in acceptable ideological packaging. In the everaccelerating universe that Burroughs describes ideologies, government systems and falsehoods race by and disintegrate into conflicts and disasters. Gabel shows us the same distorted thought patterns but far more slowly, frame by frame as it were.

\footnotetext{
${ }^{14}$ Without fear of contradiction one could argue that a theory about psychosis that does not include the mirror sign is simply not adequate to its object. See Postel and Allen (1994, pp. 675-681).

15 "We have only to understand the mirror stage as an identification...the transformation that takes place in the subject when he assumes an image..." (Lacan, 1949/2001, p. 2).

${ }^{16}$ At the end of an exchange about flying dreams with Regina Weinreich Burroughs stated that he was himself during a dream and added "The only thing was, I couldn't see myself in the mirror" (Burroughs \& Lotringer, 2001, p. 766).

${ }^{17}$ See Gabel (1975), Gabel and Sica (1997).
}

Language and Psychoanalysis, 2018, 7 (1), 35-61.

http://dx.doi.org/10.7565/landp.v7i1.1582 
Burroughs and Gabel share the idea that clinical and ideological problems are, in fact, one and the same, they are both clinicians of mad ideologies.

\section{Ontological Insecurity and Fluctuations of the Self}

In 1834 the French alienist François Leuret published the case study of a psychotic patient Catherine X (Leuret, 1834,121-24). The following is a transcript of their exchange that took place in a Paris asylum before 1834:

FL: “...please tell me your name..."

Catherine X: "The person of I-myself does not have a name...The person of Imyself has lost her name, she gave it away when she entered the Salpêtrière...The person of I-myself is the child of nobody: the origin of the person of I-myself is unknown: she has no memories whatsoever of the past". (Allen, 2015, pp. 232$233)^{18}$

The Poet John Clare spent the last part of his life at the Northampton general lunatic asylum in the U.K., here he wrote An invite to eternity:

Say, wilt thou go with me, sweet maid,

Say, maiden wilt thou go with me $[\ldots]$

Where stones will turn to flooding streams

Where planes will rise like oceaned waves [...]

Where life will fade like visioned dreams

And mountains darken into caves,

Say maiden wilt thou go with me

Through this sad non-identity... (Clare, 1848/2003, p. 276) ${ }^{19}$

Clare and Catherine both express forms of consciousness that function without subjectivity, many other witnesses clearly favour such an idea. ${ }^{20}$ The psychotic psychiatrist François Klein explained that: "There is no argument about the fact that I am not I-myself. I am my mother and my father [...] My father is not my father

${ }^{18}$ I have translated the expression 'La personne de moi-même' as 'the person of Imysel'.

${ }^{19}$ Burroughs stated clearly that to his mind "There is no such thing as an 'I'", (Burroughs \& Lotringer, 2001, p. 450).

20 "The schizophrenic patient answers the question [where are you?]...correctly ... Many times, however, he tells us that although he knows where he is, he does not feel that he is in the space he occupies, he does not feel that he is in his body, and the proposition «I exist» has no particular meaning for him" (Minkowski, 1927, p. 93).

Language and Psychoanalysis, 2018, 7 (1), 35-61.

http://dx.doi.org/10.7565/landp.v7i1.1582 
himself: he is my grandmother and my grandfather..." (Klein, as cited in Allen, 2015, p. 218). Klein goes beyond the logical affirmation of non-being and states that "The schizophrenic allows himself to be spoken [by language] as opposed to speaking [in his own name]..." (Klein, 1937/1998, p. 119).

In February 1954 Burroughs wrote a letter to Allen Ginsburg that contained the talking asshole routine that found its way into Naked Lunch in Paris in 1959. In this letter Burroughs provides a clear understanding of his particular relationship to language:

This is my saleable product. Do you dig what happens? It's almost like automatic writing produced by a hostile, independent entity who is saying in effect 'I will write what I please'. At the same time when I try to pressure myself into organizing production, to impose form on material, or even to follow a line (like continuation of novel) the effort catapults me into a sort of madness where only the most extreme material is available to me. (Burroughs, 1953-1957/1982, pp. 20-21. Italics added)

The "hostile independent entity" is perhaps a clear echo of "something terrible" that Burroughs encountered "just under the surface" when he was three years old ${ }^{21}$. Timothy Murphy in his ground breaking study ${ }^{22}$ suggests that the idea of Burroughs (Lee in the film version of Naked Lunch) writing for unknown powers is "Cronenberg's invention rather than Burroughs" (Murphy, 1997, p. 69). This may be true as far as the film goes, what is far more important however is the fact that Burroughs himself felt that he was written (or made to write!) by a "hostile independent entity" called language. In this sense Burroughs is as much a structuralist as Minkowski himself, if not more so ...

Ontological insecurity is an expression R. D. Laing uses to describe people whose sense of "autonomous identity" (Laing, 1960/1969, p. 45) is built on unsafe ground: the ontologically insecure person, Laing explains, is prone to three kinds of anguish engulfment, implosion and petrification. One of the definitions Laing gives for engulfment is particularly relevant to the universe Burroughs describes, i.e., "loss of being by absorption into the other person" (Laing, 1960/1969, p. 46). Implosion is defined as "the full terror of the experience of the world as liable at any moment to crash in and obliterate all identity, as a gas will rush in and obliterate a vacuum" (Laing, 1960/1969, p. 47). Petrification, depersonalisation and reification are found throughout the length and breadth of Burroughs forever imploding universe. Laing defines petrification as a "particular form of terror...i.e. turned to stone...the possibility of turning...into a dead thing...an it without subjectivity..." (Laing, 1960/1969, p. 48).

${ }^{21}$ In 1991, during an interview with Victor Bockris, Burroughs stated that this was his "earliest conscious memory" (Burroughs \& Lotringer, 2001, p. 802).

${ }^{22}$ See Murphy (1997).

Language and Psychoanalysis, 2018, 7 (1), 35-61.

http://dx.doi.org/10.7565/landp.v7i1.1582 
Our hypothesis is that Burroughs' work defines universal insecurity - worlds in which traditional modes of being are simply no longer available - the unembodied self - the fragment of broken selfhood is all that remains. Here are some examples taken from different parts of Burroughs' written production. In Port of saints the reader observes the conflict between the Norms who represent "the American moral disease" in its terminal stage and the "parries" who believe in paranormal experiences. "Then came the came the news that everyone longed to hear: the Parries are back...To a vast chorus of onward Christian soldiers the norms marched on Los Alamos. They did not use the atom bombs because there was nobody left who could use one" (Burroughs, 1980 , p. 23). The Norms have a precise thinking system that governs behaviour and perception; they embody "decent church-going morality" (Burroughs, 1980, p. 23). Their discourse is normative, rigid and ever suspicious ${ }^{23}$ : "Under the rule of Mike Finn it didn't pay to be good at anything...In consequence the whole structure of Western society collapsed" (Burroughs, 1980, p. 23).

There is no reason not to kill, the super-ego is absent or rejected, the "moral disease" is directed by the logic of the psychopath; the Norms are fuelled by the righteousness of fanaticism on their road to mass slaughter: "Armed with scythes and pitch forks and shot guns they marched, killing every living thing in their path" (Burroughs, 1980, p. 23). Burroughs offers little or no security for mankind; even the Norms who accept the most extreme fanatical ideology are threatened by their very companions:

As the Norms...led by Mike Finn streamed into the Parry Reservation, a great cry of rage went up: the Parries were gone. Spitting hate at the empty space, they killed all the animals they could find and then began looking at each other [...] Several hundred thousand Norms slaughtered each other on the spot. (Burroughs, 1980, p. 22)

Finally the Norms are "ploughed under" as fertilizer and yet nothing changes, conflicts move in cycles that prohibit any sense of conclusion or even a temporary improvement of the human lot: "Camera pans the scattered forces and the broken morale of the militants...teenage alcoholics, underground press closing down, black panthers finished, censorship coming back, pollution, over-population, atomic tests..." (Burroughs, 1980, p. 24). The movement of manic massacres gives way to despair often bordering on melancholia.

Within this landscape of global insecurity all values, all illusions, appear to crumble revealing madness, hatred and an unquenchable need for violent murder within the very core of modern civilised institutions:

Well an ugly thing broke out that day in the precinct this cop had worked a drunk over and the young cop had a mad look in his eyes and he kept screaming. 'Let me finish the bastard off [...]' I've seen that look before and I know what it means:

\footnotetext{
${ }^{23}$ See also Genil-Perrin (1927, pp. 203-239).
} 
'cop crazy'. When it hits they'll rush out search, sap, arrest anyone in sight. We try to cover for them. 'Son, if the cop madness come on you find an old drunken bum just as quick as you can and let yourself go'. (Burroughs, 1972, p. 162)

A specialist of collective delusions, George Heuyer, wrote that: "The feelings of crowds are closed off from doubt and uncertainty...crowds think in terms of images that follow one after the other without the least critical thought" (Heuyer, 1973, p. 37). Crowd behaviour suggests that "We" is not the plural of "I"; the crowd, as Heuyer argues is directed by image and clearly by the drive towards destruction, whereas the "I" functions within language, even if, as Burroughs argues, language is a virus. Heuyer also claims that there is something contagious about crowd behaviour (Heuyer, 1973, p. 37). Burroughs describes something comparable: “...the madness would seize whole precincts for a few minutes during which anyone in the tank is beaten to a bloody pulp..." (Burroughs, 1974, p. 163). Burroughs knows not 'seems', this allows him to write ever closer to unspeakable truths. In Port of Saints we again find a pattern of arbitrary violence: "Number 1 asks him what the Chief of Police actually does... All sorts of things. He throws people in jail and beats them up. He is also responsible for the whole police force, who are always getting drunk and shooting each other and the citizens" (Burroughs, 1980, p. 24).

The arbitrary universe obliges the reader to abandon any traditional dictionary definition in favour of meanings derived from experience and perception; thus the question 'what is a policeman?' relates to 'people who shoot citizens' as an answer. In his routines and elsewhere Burroughs demonstrates the severance of the traditional link between the word as acoustic image and the objet the image pertains to. Institutions that, in theory, serve or protect people turn against them in manic fits of totalitarian madness: "Citizens reporting to pay a parking ticket are bustled into the death cell as the berserk machine spits out random laws, warrants and sentences" (Burroughs \& Odier, 1980, p. 142). Very often Burroughs describes situations which, by definition, make any subjective response impossible, human beings are reified and finally destroyed, murdered and 'neutralised'- this last word being, in itself, an indication of reification. Whatever the ordinary citizen does she or he is always wrong, at times the world runs on double bind logic at all levels: "Every citizen of Annexia was required to apply for and carry on his person at all times a whole portfolio of documents [...] The Examiner, when he stopped a large group, would only examine and stamp the cards of the few. The others were then subject to arrest because their cards were not properly stamped" (Burroughs, 1959/1968, p. 40).

The destruction of selfhood works in two basic directions, in one case pathological institutions make life unbearable and simply impossible, in other cases the disembodied self is disconnected from the body and reduced to a ghost like existence. "I am a ghost wanting what every ghost wants - a body" (Burroughs, 1959/1968, p. 26). Whereas Henri Wallon and Lacan underline the origins of selfhood Burroughs demonstrates, over and over again, the death of the self:

'So he has an affair with this Latah, he wants to dominate someone complete the silly old thing ...' The Latah imitates all his expressions and mannerisms and 
simply sucks all the personna right out of him like a sinister ventriloquist's dummy ${ }^{24} . .$. 'You've taught me everything you are...I need a new amigo'. And poor Bubu can't answer for himself, having no self left'. (Burroughs, 1959/1968, p.

Complete characters are more than rare; generally speaking the universe, as defined by Burroughs, contains fragments or shreds of subjectivity, sound bites of extreme ideological discourse against a background of conflicts and massacres and despair that bring a fearful manic-depressive rhythm to many scenes. Fragments come into focus then fade, there is no room for any complete vision or totality and finally no hope for any kind of redemption or improvement of modern man.

If we consider extreme situations there are clear parallels between the bureaucratic dehumanisation that Burroughs describes and the logic of reification found in concentration camps. Niederland lists the following characteristics of concentration camp life:

1. ... life endangering situation...total helplessness.

2. Chronic starvation - from 1400 later 600 calories.

3. Physical maltreatment with fear of total annihilation.

4. Total degradation to the point of dehumanisation ${ }^{25}$.

5. Recurrent terror episodes.

6. Total family loss.

7. Abrogation of causality.

${ }^{24}$ In 1945 Ealing studios released a horror film, made up of several different dream narratives, entitled Dead of night; it included a long sequence called 'The ventriloquist's dummy' in which the ventriloquist (Michael Redgrave) is possessed by his dummy who finally betrays him...The film also includes a dream sequence concerning a racing driver who has a bad accident; in hospital he dreams of an undertaker who says "room for one more inside sir"whilst driving a hearse, this is clearly an invitation to death. Miles Malleson repeats the phrase a second time in the same film sequence but this time as a London bus conductor. The bus crashes with passengers mangled to death, the wounded racing driver refuses the invitation twice. Burroughs uses the invitation in the post-script to the introduction of Naked Lunch with capitals as follows "Room for One More Inside, Sir" (p. 16). The invitation is repeated page 17 without the additional capitals, and again page 257 as "...Room for one more inside" as if to emphasise the lasting nature of the death drive that invites the Junky into the cold. Burroughs may well have seen the film in London or elsewhere.

${ }^{25}$ Whilst using a sleeping pill called Soneryl Burroughs dreamt that he'd "been in a prison camp for years suffering from malnutrition..."(Burroughs, 1959/1968, p. 86)

Language and Psychoanalysis, 2018, 7 (1), 35-61.

http://dx.doi.org/10.7565/landp.v7i1.1582 
8. Assaults on and impairment of identity with changes of self-image; selfestrangement.

9. Prolonged "living dead" existence with no way out and growing feeling that one's 'non-existence is entirely possible' (Erolson) leading into...stupor [and] death (Krystal, 1968, p. 64).

Many passages of Naked Lunch deal with racism and anti-Semitism in the USA, the analysis of various ideologies allow Burroughs to combine different aspects of totalitarian control systems. The oft repeated references to "the ovens" might indicate that genocide, as a historical possibility, has been absorbed into what Timothy Murphy ${ }^{26}$ calls an "amodern" perspective. Burroughs offers a kaleidoscope of totalitarian perspectives which subsumes every shade and hue of dictatorships past, present and future. At the "Meet Cafe'" in the "City Market" alongside black marketeers of WW III we find "bureaucrats of spectral departments, officials of unconstituted police states" (Burroughs, 1959/1968, p. 130). In other words if there is any continuity in what Burroughs calls the "biologic film" it is the continuity of the negation of freedom, the police state leitmotif that works even better when the policeman is internalised by a submissive population. Dr Benway is very clear on this point: "A functioning police state needs no police" (Burroughs, 1959/1968, p. 54). Benway abolishes concentration camps and mass arrest because, to his mind, they are not efficient enough. "On the other hand, prolonged mistreatment...gives rise...to anxiety and a feeling of special guilt. [...] The subject must not realize that the mistreatment is a deliberate attack of an anti-human enemy on his personal identity" (Burroughs, 1959/1968, pp. 39-40).

The human subject is wrong and, with a clear nod in the direction of Kafka's Trial, it is impossible to know what he is guilty of. In this post-concentration camp perspective the law has "melted", there is no law ${ }^{27}$ of any sort, not even the arbitrary

26 "...the primary forms of racism analysed in Naked Lunch are American antiSemitism and anti-black racism..." (Murphy, 1997, p. 93). Murphy also mentions "the racists' paranoid control hallucinations..." (Murphy, 1997, p. 92). The late Joseph Gabel often compared racist logic to paranoia, in both cases, he would argue the Other who persecutes is a figment of a fanatical imagination bearing "the stigma of society's disavowal of its of its own determining characteristics" (Murphy, 1997, pp. 92-93). The racism that Burroughs sees as a central ideological element to political life in the USA has amplified in accordance with what Burroughs predicted in The Electronic Revolution. “...Trump's win was a triumph of the hideous racism, sexism and xenophobia that has always run through American society" (Taibbi, 2017, p. 285).

${ }^{27}$ After the final solution, Hiroshima, Pinochet, Stalin, Petain, Maggie Blair, and ... what Law can be seen to protect the human subject or regulate his exchanges? "Arbeit macht frei"- Work bestows freedom (sic)... This slogan was found on a gate to Auschwitz during WW II. Clearly there is little or no real Law after 1945, and there no are such thing as Laws beyond 'the algebra of need' in the worlds Burroughs describes, indeed he is perhaps the first artist to have completely absorbed the totalitarian experience as a defined - and dominant - category of Language and Psychoanalysis, 2018, 7 (1), 35-61.

http://dx.doi.org/10.7565/landp.v7i1.1582 
link between the acoustic image and the concrete object. In this lawless land the nonbeing of the disembodied self is, for the greater part of the population, the last resort. The idea that non-existence is possible is not only found in concentration camps - it is also established in the cases of Catherine X, Clare and of course Klein. Selfhood is simply not a viable possibility in the lawless universe that Burroughs defines:

Aracknid is a worthless chauffer, barely able to drive. ...He ran down a pregnant woman...with a load of charcoal on her back, and she miscarried a bloody dead baby in the street...the police questioned Aracknid and finally arrested the woman for a violation of the sanitary code'. (Burroughs, 1959/1968, p. 40)

The law is defined as an arbitrary force that functions without reason: "As one judge said to another: 'Be just and if you can't be just be arbitrary"' (Burroughs, 1959/1968, p. 22). In The ticket that exploded the writer goes as step further by suggesting that advanced technology has simply put an end to any laws: "You can look any place...technical brains melted the law" (Burroughs, 1967, p. 172). Without law, and without the super-ego to provide individual law, only the most destructive human drives find expression:

I saw women thrown down on Fifth Avenue and raped in their mink coats...while street urchins stripped the rings from their fingers. [...] I found Colonel Bradshaw bivouacking in the Ritz. I told him bluntly what was going on. His eyes glinted shamelessly as he said: 'Well you have to take a broad general view of things'. And that's what I've been doing. Taking a broad general view of American troops raping and murdering helpless civilians while American officers stand around and yawn. (Burroughs, 1974, p. 115)

On occasions ideological justifications appear for wars and massacres:

General Greenfield on a white horse speaks from the top of Art hill. ...'Over there'... 'Across the Atlantic is a sink of iniquity... A latter day Sodom and Gomorrah. ...All over America kids like Johnny are deserting this country and their great American heritage suborned by the false promises of Moscow into a life of drugs and vice. I say to you all that wherever anarchy, vice and foul corruption rears the swollen head of the cobra to strike at everything we hold sacred, the very heart of America is threatened. (Burroughs, 1974, pp. 96-97)

experience and being. What French analysts call 'le grand Autre' (the big Other) is simply a fairy tale comparable to Father Xmas or the pot of gold that one is supposed to find at the end of the proverbial rainbow. 
If we accept the idea that Burroughs wrote one long book ${ }^{28}$ we could study the patterns behind events, the causal logic that is established; often, as we see above, ideological fragments are the cause of events - as if historical events were simply accidents or ideological by-products: “...we could have profited from the French experience in Viet-Nam. It showed that this was a war that couldn't be won. I would have opposed the Viet-Nam war even on military grounds. And there was no reason for it. It was completely an ideological conflict" (Burroughs, 1974, p. 533). Joseph Gabel often argued that ideology, like certain forms of psychosis, is impervious to experience.

\section{The Body ...}

A psychotic patient wrote: "I appear to be an empty bedroom, the tenants change endlessly. What is the point of expelling them? They have the nerve to come back". ${ }^{29}$ Another patient stated that: "I no longer have a body, I am a semblance of flesh. I do not live. We are dead before being in the world". "The idea of the body as a space that can be occupied and vacated is a feature of Spike Milligan's The Bedsitting Room $^{31}$; in this bleak black post-nuclear war comedy Lord Fortnum battles with the idea that he is turning into a cheap room for rent... The play has many other melancholic qualities including despair and the idea of the end of the world, clinical signs that clearly belong to Cotard's syndrome (Enoch \& Trethowan, 1979, pp. 116133). The non-relationship between the body and identity is a constant feature of Burroughs' œuvre:" Bill and Johnny we sorted out the names but they kept changing like one day I would wake up as Bill the next day as Johnny" (Burroughs, 1967, p. 12-13). The body is seen in terms of need as opposed to desire and most often even the temporary occupation of a body is seen as dangerous. Psychiatry, Burroughs argues, works against selfhood by encouraging medical forms of reification. Consider Dr Schafer's paper as presented to the International Conference of technological psychiatry:

'Gentlemen, the human nervous system can be reduced to a compact and abbreviated spinal column. The brain, front middle and rear must follow the adenoid, the wisdom tooth, the appendix...I give you my master work: The Complete All American De-anxietized Man ...' (Burroughs, 1977, p. 81)

Technology has removed any risk of selfhood, lobotomy ${ }^{32}$, as a metaphor for modern man, has "reduced man to the mere essentials" (Burroughs, 1977.). Modern man may

\footnotetext{
28 "It's all sort of one book really..." (W. S. Burroughs in Burroughs \& Lotringer, 2001, p. 728).

29 "Je fais l'effet d'une chambre vide, dont les locataires se renouvellent sans cesse. A quoi sert de les expulser? Ils ont l'effronterie de revenir" (DanonBoileau, 1980, p. 127).

30 “Je n'ai plus de corps, je suis un semblant de chair. Je ne vis pas. On est mort avant d'être au monde" (Danon-Boileau, 1980, p. 126).

${ }^{31}$ Milligan and Antrobus (1970).

${ }^{32}$ For a clear account of the barbaric nature of psychosurgery see Valenstein

Language and Psychoanalysis, 2018, 7 (1), 35-61.

http://dx.doi.org/10.7565/landp.v7i1.1582
} 
produce and consume, he does not have to think or worry about anything, he is a 'thing' in a 'thing-world' where the only law or discernible pattern is one of need, merchandise and reification of every shade and hue. The "algebra of need" finds its roots in the process of addiction as illustrated in Junky (1953); heroin is the blueprint of a more general control system ${ }^{33}$. Values, in the landscape found in Naked Lunch and beyond, are always mercantile values; orgasm, heroin, parts of the body - most areas of experience are broken down into quantative elements only. Need is the veritable negation of freedom; it is also the guarantee of an everlasting consumption of merchandise so that the ideology of merchandise is itself dependant on the maintenance of absolute need within a captive population. TRAK, in the Soft Machine, combines the ideology of merchandise with absolute need; the relationships between need and merchandise dissolve the very possibility of subjectivity. The road to selfhood is barred by cellular need:

The perfect product, gentlemen, has precise molecular affinity for its clients [...]

Our product never leaves the customer. We sell servicing and all Trak products have precise need of trak servicing [...] This is not just another habit forming drug this is the habit forming drug [that] takes over all functions... (Burroughs, 1967, p.

Eric Mottram (1969/1977), in the first complete study of Burroughs as a theorist of modernity $^{34}$, argued that:

In the Soft Machine the algebra of need and the invention of the perfect product are fused into Trak Servicings, a total servicing organisation, a brilliant parody of intermeshed business and consumer controls, the ultimate habit-forming drug which finally takes over the consumer-addict and reduces him to the helplessness of a larva [...] The funfairs and sideshows...provide the state's parasites with their basic needs. The gods are fakes. The real control is Trak ${ }^{35}$ Sex and Dream Utilities, whose aim is total satisfaction and whose actions are protected by the Thing Police... (Mottram, 1969/1977, p. 65)

(1986).

33 "1- Never give anything away for nothing. 2 - Never give more than you have to give (always catch the buyer hungry and always make him wait). 3 - Always take everything back if you possibly can" (Burroughs, 1959/1968, p. 8).

${ }^{34}$ Mottram (1969/1977).

35 "...the forces of evil are represented by a Scandinavian tycoon head of Trak Inc., who control the Sex Utilities of most of the world. That is they can disconnect your orgones...". Burroughs, letter to Allen Ginsburg, November, 1957 (Burroughs, 1993, p. 377).

Language and Psychoanalysis, 2018, 7 (1), 35-61. 
It is no longer possible to entertain jouissance within the framework defined by the Oedipus complex or even conscious or unconscious desire because: "All are dependent on Trak for their lives such as they are" (Burroughs, 1967, p. 36). Trak controls and services sex, dreams and need of the greater part of the population of the world: Burroughs is perhaps the first post-Auschwitz post-Hiroshima writer to theorise a modification in the nature of jouissance. Oedipal jouissance is fading to reveal a change in the very constitution of the object. Truth about the object as established by Sophocles, Shakespeare and Freud gives way, Burroughs argues, to chemistry, biology and electricity along with the irreversible separation of body and identity. The traditional order of jouissance, Burroughs argues, is toxic:

We intend to march on the police machine everywhere. We intend to destroy all dogmatic verbal systems. The family unit and its cancerous expansion into tribes, countries, nations we will eradicate at its vegetable roots. We don't want to hear any more family talk, mother talk, father talk, priest talk, country talk or party talk. To put it country simple we have heard enough Bullshit. (Burroughs, 1974, pp. 109-110)

The unstable nature of the body was already sketched out in Junky (1953):

When I closed my eyes I saw an oriental face, the lips and nose eaten away by disease. The disease spread, melting the face into an amoeboid mass in which the eyes floated, dull crustacean eyes. Slowly, a new face formed around the eyes. A series of faces, hieroglyphs, distorted and leading to the final place where the human road ends, where the human form can no longer contain the crustacean horror that has grown inside it. (Burroughs, 1953-1977, p. 133)

Such bodies allow no "unquestionable self-validating certainties" (Laing, 1960/1969, p. 39), human identity, such as it is, is perpetually besieged by angst, a sense of danger both without and within. In the above extract the faces are defined as hieroglyphs as if the movement towards crustacean existence was in itself a message to be deciphered. A significant part of Burroughs written work is devoted to a quest for other forms of language, his mistrust of "dogmatic verbal systems" is well known: "The word is now a virus [...] The word may once have been a healthy neural cell. It is now a parasitic organism that invades and damages the central nervous system" (Burroughs, 1967, p. 49).

In 1939, notes Oliver Harris, "Burroughs attended a series of lectures at the... Institute of General Semantics given by Korzybski...” (Burroughs, 1993, p. 44). Burroughs was clearly influenced by the idea that our linguistic system is in itself an alienating force; Korzybski ${ }^{36}$ had studied psychotic speech patterns and advanced the

\footnotetext{
${ }^{36}$ For a detailed account of the function of the verb 'to be' in psychosis (Allen,
} 2015).

Language and Psychoanalysis, 2018, 7 (1), 35-61. 
idea that in heavy cases of dementia praecox (schizophrenia) the most highly developed forms of identification are to be found.

The idea of the word as a virus runs parallel to the "empty body" (Burroughs, 1967, p. 82) programme of ritualised reification, the body is drained of its vitality by the inhabitants of hanging vine country who run the programme. The inhabitants live: "in translucent jelly and converse in light flashes liquify bones of the world and eating the jelly" (Burroughs, 1967, p. 82). The dissolution of the body reduces communication to the on/off function of a light switch or a torch, we are close to what Freud called 'organ speech' as if parts of the body were expressed directly in reified patterns that short-circuited the representation of things and centred on words (verbal labels/acoustic images) alone.

In strictly clinical terms patients express themselves as follows:

It tears all my body away. Everything shakes within me from head to foot. It's so funny that we don't know if we still have blood in our veins. At any time it moves into the teeth and curls up. I feel that I'm going to fall into pieces on all sides. My impression is that I feel myself getting thinner. I feel my body going away on all sides. [The area] above my teeth is being torn away; before only my gums were torn away. My nails are hurting me as is the rest of my body. (Danon-Boileau, 1980 , p. 51)

As we can see organ speech involves intense word cathexis ${ }^{37}$ and shows how the relation to one organ can represent the entire content of a patient's thoughts as unrecognised metonymy. An organ or orifice can embody the Other as agent of persecution ${ }^{38}$. Organ speech is not metaphor, on the contrary it is to be read au pied de la lettre, at the very foot of the letter as the French say. In Naked Lunch and elsewhere $^{39}$ bodily organs are often described as independent entities, the most famous case is one of Dr Benway's inventions:

${ }^{37}$ See Dalzell (2011, pp. 88-91) and Mary (1999, pp. 17-63).

${ }^{38}$ James Frame (1860) argued that the stomach was often the evil Other that persecuted melancholic patient in his remarkable autobiography The Philosophy of Insanity.

${ }^{39}$ Spare ass Annie appeared in 1982 in Early Routines published in Santa Barbara by Cadmus editions (pp 13-14) she returned in the cd of the same name in the early 1990s. The drives, oral, anal, genital and scopic never combine in an organised montage - they are either presented as isolated fragments, as in the talking asshole routine or spare ass Annie, or as absolute needs to absorb others in routines such as Willy the disk and Bradley the buyer. Here again we find elements close to Freud's idea of organ speech. One of the elements that forever separates Burroughs' work from mainstream products is the fact that Burroughs never gives in to the idea that the drive should be connected to language, this is what makes the question of organ speech so essential.

Language and Psychoanalysis, 2018, 7 (1), 35-61. 
Did I ever tell you about the man who taught his asshole to talk? [...] This man worked for a carnival...it was like a novelty ventriloquist act. ...He had a number that was a scream... Like, 'Oh I say, are you still down there, old thing?' 'Nah! I had to go relieve myself’. (Burroughs, 1959/1968, pp. 153-154)

A. J. is also an adept of organ speech: ...Boy in Los Angeles fifteen years old. Father decide it is time the boy have his first piece of ass...father go out and say: 'Son here's twenty dollars; I want you to go to a good whore and a piece of ass off her'. 'So they drive to this plush jump joint and the father say, 'All right, son...So ring the bell and when the woman come...tell her you want a piece of ass'. [...] Fifteen minutes later the boy comes out:

'Well, son, did you get a piece of ass?'

'Yeah. This gash comes to the door, and I say I want a piece of ass and lay the double sawski on her. We go up to her trap, and she remove the dry goods. So I switch my blade and cut a big hunk off her ass, she raise a beef like I am reduce to pull off one shoe and beat her brains out. Then I hump her for kicks'. (Burroughs, 1959/1968, pp. 140-141).

Again the word is disconnected from its area of possible meanings ${ }^{40}$, the combination of the first and the third person of the singular - 'she remove' - adds to the idea of language as a mechanical reified code; there is no unified libidinal body as one would find in a love story, here we have isolated parts of the body that appear to be radically distanced from any kind of unity or totality. At best, in The Naked Lunch, characters dream of a dramatic change that would replace the body with a gigantic all-purpose blob or, in Exterminator, reduce humanity to one last person who would no longer be bothered by the potentially antagonistic will of others.

Willy the disk is a junky police informer who hunts addicts down, he represents a concentrated oral drive and aims to "suck the juice right out of every junky he ran down" (Burroughs, 1959/1968, p. 25).

He is a frightening example of the algebra of need and a threat to junkies everywhere; no body is safe. The oral drive that sets Willy in motion is both endless and lawless: "When they move in for the bust, Willy goes all out of control, and his mouth eats a hole right through the door" (Burroughs, 1959/1968, p. 25). The idea of bodily absorption is a central aspect in the story of Bradley the buyer. The logic of organ speech is in part replaced by the transformation of the body into a blob of soft jelly. Although Bradley is not a junky he needs to rub up against junkies to "get fixed" (Burroughs, 1959/1968, p. 33). As he himself is caught up in the algebra of need he

\footnotetext{
40 The signifier is divorced from the signified one could argue, the metonymy is not recognised as such.
}

Language and Psychoanalysis, 2018, 7 (1), 35-61. 
loses control of whatever selfhood he ever had. His "habit keeps getting heavier [...] It gets to a point where no amount of contact will fix him" (Burroughs, 1959/1968, p. $34)$.

Within the framework of modern administrative logic Bradley is summoned by the district supervisor who has to maintain appearances and protect the reputation of the department. He asks for the buyer's immediate resignation.

The Buyer throws himself to the ground and crawls over to the D. S. 'No, Boss Man, no...The department is my very lifeline. [...] Please Boss Man, I'll wipe your ass, I'll wash out your dirty condoms' [...] The D. S. retches into his handkerchief and points to the door with a limp hand. The Buyer stands up...His body begins to dip like a dowser's wand. He flows forward ...

'No! No! screams the D. S.

Schlup...schlup schlup'. An hour later they find the Buyer on the nod in the D. S.'s chair. The D. S. has disappeared without trace. (Burroughs, 1959/1968, p. 35)

We have tried to show that the body is oft presented as fragments, orifices, bits and pieces... We are light years away from the idea of a unified body with coordinated drives that can be absorbed and symbolised within speech. In other situations we find the idea of a body that absorbs other bodies as is the case for Bradley the Buyer. These very different positions are not presented in conflict with each other, rather they move in parallel like a river and its banks. Changing, exchanging or modifying bodies can entail complete transformations of being, memory and past history; consider the complaints lodged by the male hustler in the chapter titled 'Ordinary men and women' of The Naked Lunch.

Male Hustler: "What a boy hasta put up with in this business. Gawd! The propositions I get you wouldn't believe it...They wanta play Latah, they wanta merge with my protoplasm, they want a replica cutting, they wanta suck my orgones, they wanta take over my past experience and leave old memories that disgust me...

I am fucking this citizen so I think, 'A straight John at last'; but he comes to a climax and turns himself into some kinda awful crab...I told him, 'Jack, I don't hafta stand still for such a routine like this...You can take that business to Walgreen's. Some people got no class to them. Another horrible old character just sits there and telepathizes and creams in his dry goods. So nasty". (Burroughs, 1959/1968, 146-147). 
The hustler is, as Burroughs says, an ordinary person; within the algebra of need prostitution is a banal aspect of everyday life, orifices of the body are but merchandise to be bought and sold, the very nature of modern economics devalues and destroys any possible link between selfhood and the lived body. Even those who sell their services to Bradley the buyer accept their lot as if selling their bodies was the only way to survive:

'Most distasteful thing I ever stand still for', he says. 'Some way he make himself all soft like a blob of jelly and surround me so nasty $[\ldots]$ he come to some kinda awful climax $[\ldots]$ '

'Well it's still an easy score'

[...] 'Yes, I guess you can get used to anything. I've got a meet with him again tomorrow'. (Burroughs, 1959/1968, p. 34)

Bodies and selfhood are dangerously unstable elements, they can be exchanged, modified or fragmented there is no question of any kind of primary identification with the body, no hope for ontological security of any kind.

\section{Towards a Handbook of Global Psychopathology}

Our hypothesis regarding the mirror sign, central to any understanding of Burroughs' ideological critique, is based on the hints and clues that he himself left for the reader to find. Consider the following paragraphs from the closing section of The Naked Lunch:

The writer sees himself reading to the mirror as always...He must check now and again to reassure himself that The Crime Of Separate Action has not, is not, cannot occur... Anyone who has ever looked into a mirror knows what this crime is and what it means in terms of lost control when the reflection no longer obeys. (Burroughs, 1959/1968, p. 249)

If the mirror sign indicates the destruction of selfhood and a possible divorce from the inhabited body then it is not only logical but necessary to read Burroughs as an introduction to global psychopathology. At this point the relationship between Burroughs fragmented universe and Gabel's extensive work on false consciousness becomes very clear. Joseph Gabel - a trained psychiatrist who turned to the sociology of knowledge - uses different forms of psychotic reasoning in order to study the structure of different kinds of totalitarian discourse. In his work he was greatly influenced by Eugene Minkowski - the first thinker in the history of ideas to introduce the notion of structure into psychopathology in the early 1920s. Gabel argues, over and again, that elements comparable to psychotic logic are to be found at the very core of extreme ideologies. Burroughs sometimes argued that the age of Stalin and Hitler was over, this does not mean an end to economic chaos, unemployment, estrangement or corruption. On the contrary Burroughs argues that 
the rulers "of this most insecure of all worlds are rulers by accident, inept, frightened pilots at the control of a vast machine they cannot understand, calling in experts to tell them which buttons to push" (Burroughs, 1982, p. 31). Burroughs defines different kinds of false consciousness mainly based on the ideology of merchandise whereas Gabel thought that the fetish value of merchandise would continue in modern life as a reward that ideology might offer. At times Burroughs mentions forms of false consciousness that correspond to Gabel's idea of a blind spot within thought: "The trouble is the unions'. They would say it spitting blood from radiation sickness. Or in the process of turning into crustaceans" (Burroughs \& Ginsburg, 1981, p. 15). Gabel argues with great skill that ideology - what Burroughs calls 'the reality studio'produces the lived present whereas within the logic of the algebra of need Burroughs shows how ideology and merchandise have merged into one pathological entity. What binds the thinkers is a shared understanding of the place of reification; for Gabel reification is a result either of clinical psychosis or the result of what I call "concentrated ideology", Burroughs identifies reification as a result of the invasion, or even the replacement, of selfhood by the need for merchandise.

In many parts of Naked Lunch we find latahs and replicas as if Burroughs was hinting at a kind of universal Capgras syndrome ${ }^{41}$, copies copying other empty copies. Dr. Lee is unsatisfied with the world as he finds it; at one point, in order to be safe at last, he decides on a radical solution to the self/body question:

...he decided to end the whole distasteful thing once and for all by turning everyone into himself [...] he called it the 'beautiful disease' [...] his boat is moored by the pier...it is a small boat and he can handle it alone...last awning flaps on the pier...last man here now. (Burroughs, 1974, 45)

There are clear indications of individual psychosis of course: in 23 Skidoo Burroughs reinvents a kind of influence syndrome. "A2 "Assasins often hear voices telling them to kill...As he struck the assassin was heard to say "After all God made knives" (Burroughs \& Odier, 1980, p. 83-84). Psychosis spreads in the

'23 Screwball department'...At the office party Mr Blankslip from accounting mixed his "blackout special" and a little cold voice told him this man must be killed to save the Lamb of God [...]

\footnotetext{
${ }^{41}$ See Enoch et al. (1979, p. 1-14). In this syndrome people feel that other people are clones or copies and that the 'real' people have been removed somehow. It is close to the Frégoli syndrome in which a person feels followed or threatened by someone who changes his face and appearance very quickly and very often. Again we find the unstable relationship between being and body.

${ }^{42}$ A clear case of the influence syndrome was published by J. Haslam in London, 1810, this was republished as Illustrations of Madness (1988) edited with an introduction by the late Roy Porter. Earlier descriptions of this psychotic syndrome may exist, I have not come across them.
}

Language and Psychoanalysis, 2018, 7 (1), 35-61. 
Clearly O. I.- Outside Influence - is at work. (Burroughs \& Odier, 1980, pp. 85$86)^{43}$

Beyond individual cases of psychosis occasional manic-depressive swings can be seen, in The Soft Machine we find the manic ability to join in whatever is going on: "By this time there were soldiers everywhere shooting the civilians so we scored for some civil war uniforms and joined one of the warring powers" (Burroughs, 1967, p. 13). Often manic explosions of violence and sexuality are in stark contrast with the expression of black despair and a sense of mass destruction. Indeed, Cities of the Red Night closes with:

I am in a beautiful garden, as I reach out to touch the flowers they wither under my hands. A nightmare feeling of foreboding and desolation comes over me as a great mushroom cloud darkens the earth. A few may get through the gate in time. Like Spain I am bound to the past. (Burroughs, 1981, p. 332)

Melancholic despair is outlined in Exterminator as a collective prelude to the breakdown of civilisation as we know it:

Unpaid bills unanswered letters each simple task an agony to perform everyday a little worse and the worse it got the less was happening as the structure quietly foundered whole apartment blocks phone in to say they won't be coming in to the office that day and nobody is there to take the calls. The writer flinches from his typewriter the cop turns sick with the sight of his badge. Tools fall from slack hands plows gather dust in ruined barns. (Burroughs, 1974, p. 122)

Within what is perhaps the first ever handbook of global psychopathology merchandise is progressively adulterated: whores might be cut with "sponge rubber" (Burroughs \& Ginsburg, 1981, p. 9), the heroin is cut with milk and sugar or strychnine (Burroughs, 1959/1968, p. 20), famous restaurants serve pure garbage ${ }^{44}$. Burroughs' ferocious critique of merchandise as both the basis and result of modern life ${ }^{45}$ at times bring him close to ideas expressed by G. Debord.

Is this bread, wine, a tomato, an egg, a house, a town? Certainly not, because a series of internal transformations, economically useful in the short term to those who control the means of production, has maintained the names and an important

${ }^{43}$ Auditory hallucinations in psychosis may be a soundtrack version of the gaze of the Other.

${ }^{44}$ The menu Chez Robert includes "Clear camel piss soup with boiled earthworms" as a first dish (Burroughs, 1959/1968, p. 172)

45 "They are rebuilding the City' Lee nodded absently... 'Yes.... Always'” (Burroughs, 1959/1968, p. 261).

Language and Psychoanalysis, 2018, 7 (1), 35-61.

http://dx.doi.org/10.7565/landp.v7i1.1582 
part of the appearance but removed the taste and the content. (Debord, 1992, p. 110)

The subject as defined by Shakespeare has lost ground as a dominant representation of mankind. Along side it we now find the " 21 st Century Schizoid" 46 man; a fragment of consciousness defined by merchandise within the area attributed to him by the algebra of need. When Orwell first published 1984 and Animal Farm he was treated with disdain, he was a failed science fiction writer, at best a critic of Stalinism - and that was the end of him. Today we understand Orwell as a theorist of everyday life in modern countries ${ }^{47}$. He has become a social realist so to speak.

Burroughs knows not 'seems'; his work is not only a preliminary map of the 21 st century but also a solid critique of the ideology of merchandise. When The Naked Lunch was first published in Paris in 1959 the idea of anybody playing "chicken with passenger planes" (Burroughs, 1959/1968, p. 63) struck the reader as extreme or impossible. After the attack on the world trade centre on the 11th of September 2001 it became necessary to read Burroughs with a little more attention. He paints a world of amplified conflicts, corruption, intolerance, wars, bankruptcy and abuses of power. Addictions of every shade and hue have all but replaced subjectivity in the uncertain future of polluted mankind. We may, of course, try to blind ourselves and hope that Mr. Burroughs is wrong in his descriptions of schizoid ${ }^{48}$ awareness within global ideological madness. Naturally, we'd be very wise not to bet on it.

\footnotetext{
46 “Cat's foot, iron claw - Neuro-surgeon's scream for more - At paranoia's poison door - Twenty first century schizoid man", King Crimson, In the Court of the Crimson King, see first released in 1969 by Island records.

${ }^{47}$ See Leys (1984).

${ }^{48}$ Helene Deutsch (1965) gives a reasonably clear incomplete description of schizoid being. See also Allen (2017).
} 


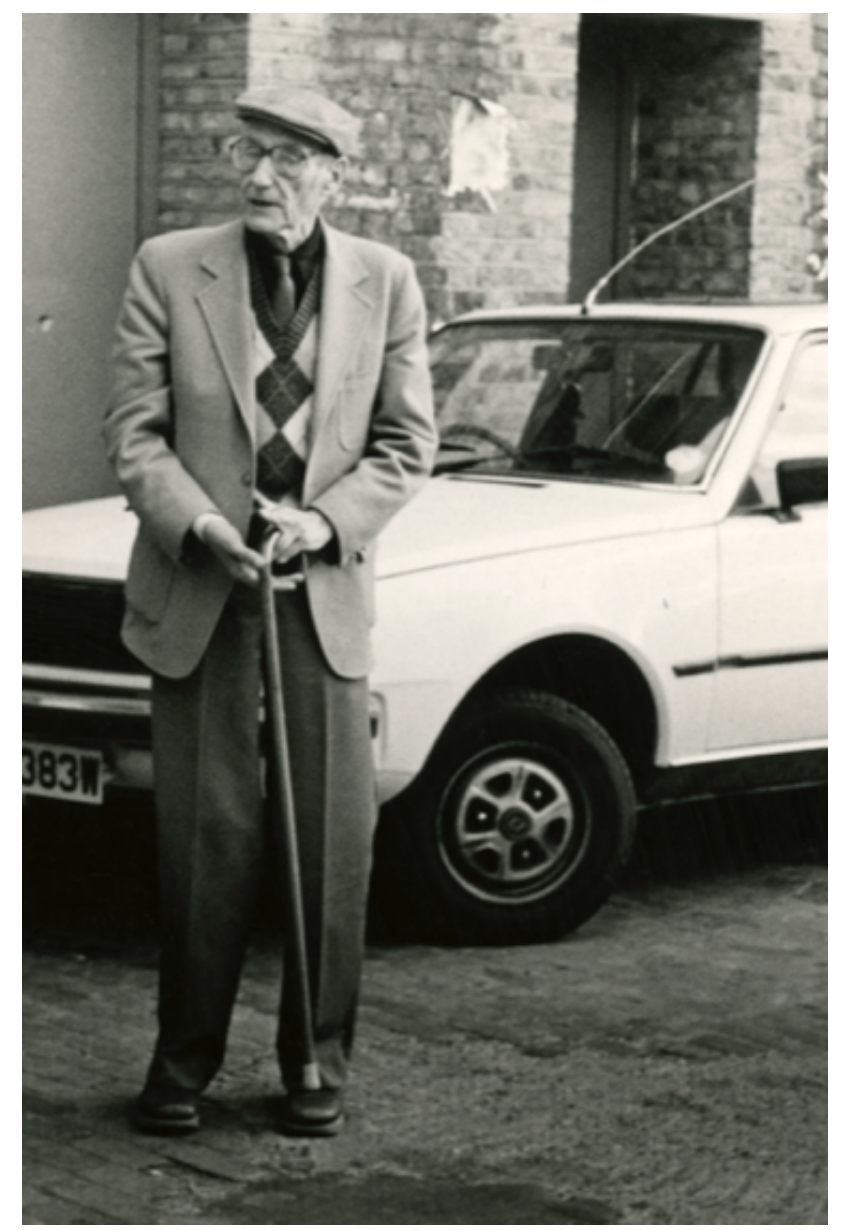

Figure 2

W. S. Burroughs a day or two before his public reading in Brixton, 1982, just after the riots.

\section{Author's Biography}

David Frank Allen was born in Vienna when the city was divided into four zones. He did his Ph. D. at Paris 7 and began working with psychotic patients in 1985 . He also worked as a lecturer in adult psychopathology before turning to full time work as an analyst in Paris. He has published widely in English, French, Greek and so on. Recent publications include a study of irony and black humour in manic-depression (Psychologie Clinique, 2018, $\mathrm{n}^{\circ} 1$ ) and a translation of James Frame's The Philosophy of Insanity (1860), Paris, EPEL, October 2018. He hopes to produce a UK edition of this work which would include clinical notes on Frame written in the 1850s.

\section{Acknowledgment}

I would like to thank the reviewers who helped me to sharpen this article in many ways. Heartfelt thanks also to Dr. Laura Cariola who edited this study into publishable form. 


\section{References}

Allen, D. (2015), Critique de la raison psychiatrique, éléments pour une histoire raisonnée de la schizophrénie. Paris, France: In Press.

Allen, D. (2017). Schizoïdie et mélancolie simple: les psychoses discrètes. L'Information psychiatrique; 93, 685-91.

Abraham, K. (1949). The psycho-sexual differences between hysteria and dementia praecox in Selected papers on psychoanalysis. London, UK: Hogarth Press. (Original work published 1908)

Bullock, A., \& Stallybrass, O. (1977). Dictionary of modern thought. London, UK: Fontana.

Burroughs, W. S., \& Odier, D. (1980). The job. New York, NY: Grove Press.

Burroughs, W. S. (1959/1968). Naked lunch. London, UK: Corgi Books.

Burroughs, W.S. (1967). The ticket that exploded. New York, NY: Grove Press.

Burroughs, W. S. (1982). Early routines. Santa Barbara, CA: Cadmus Editions.

Burroughs, W. S., \& Ginsburg, A. (1981). The yage letters. San Francisco, CA: City Lights.

Burroughs, W. S. (1979). Roosevelt after inauguration. San Francisco, CA: City Lights.

Burroughs W. S. (2000). Last words. New York, UK: Grove Press.

Burroughs W. S. 1974). Exterminator. London, UK: Calder \& Boyars.

Burroughs W. S. (1982). Letters to Allen Ginsberg, 1953-1957. New York, NYL Full Court Press.

Burroughs, W. S. (1974). The wild boys. London, UK: Corgi.

Burroughs, W. S. (1977). Junky. London: UK, Penguin.

Burroughs, W. S. (1967). The soft Machine. London, UK: Corgi.

Burroughs, W. S. (1977). Dead fingers talk. London, UK: W. H. Allen.

Burroughs, W. S. (1993). The letters of William S. Burroughs, 1945-59. London, UK: Penguin.

Burroughs, W. S. (1980). Port of Saints. Berkeley, CA: Blue Wind.

Crystal, D. B. (2002). Shakespeare's words. London, UK: Penguin Books.

Clare, J. (2003). I Am, selected poetry of John Clare. New York, NY: Farrar, Straus \& Giroux. (Original work published 1848)

Dalzell, T. G. (2011). Freud's Schreber. London: UK, Karnac.

Danon-Boileau, L. (Ed) (1980). Textes sans Sépulture. Paris, France: Inter-Editions.

Debord, G. (1992). Commentaires sur la société du spectacle \& Préface à la quatrième édition italienne de La société du spectacle. Paris, France:,Gallimard.

Deutsch, H. (1965). Neuroses and character types. New York, NY: IUP. (Original work published 1936)

Enoch, M,. \& Trethowan, W. (1979). Uncommon psychiatric syndrome. Bristol, UK: Wright.

Frame, J. (1949). The philosophy of insanity. New York, NY: Greenberg. (Original work published 1860)

Freud, S. (1961) Neurosis and psychosis and the loss of reality in neurosis and psychosis. S.E. XIX. London, UK: Hogarth Press. (Original work published 1923)

Gabel, J. (1961/1975). False consciousness: an essay on reification. (M. A. Thompson Trans.). Oxford, UK: Blackwell.

Gabel, J. (1997). Ideologies and the corruption of thought. New Brunswick:, NJ Transaction Publishers.

Language and Psychoanalysis, 2018, 7 (1), 35-61.

http://dx.doi.org/10.7565/landp.v7i1.1582 
Genil-Perrin, G. (1927). Les paranoïaques. Paris, France: Maloine.

Shakespeare W. (1936). Hamlet. text established by J. Dover Wilson, London, CUP. Haslam, J. (1988). Illustrations of madness. London, UK, Routledge. (Original work published 1810)

Hérouard, B. (Ed) (1993). Ecrits inspirés et langue fondamentale. Paris, France: Epel. Heuyer, G. (1973). Psychoses collectives et suicides collectifs. Paris, UK, PUF.

Jackson S. W. (1986). Melancholia and depression. New Haven, CT: Yale University Press.

King Crimson (1969). In the court of the crimson king. Island Records, CD.

Klein, F. (1998). Une folie psychiatrique. Paris, France: Les Empêcheurs. (Original work published 1937)

Krystal, H. (Ed) (1968). Massive psychic trauma. New York, NY: Indiana University Press.

Lacan, J. (2001). The mirror stage, in Ecrits: a selection (A. Sheridan Trans.).

Oxford, UK: Routledge. (Original work published 1949)

Laing, R. D. (1960/1969). The divided self. New York, NY: Pantheon Books.

Leuret, F. (1834). Fragments psychologiques sur la folie. Paris, France: Crochard.

Leys, S. (1984). Orwell ou l'horreur de la politique. Paris, France: Hermann.

Burroughs, W. S., \& Lotringer, S. (Ed.) (2001). The collected interviews of William S. Burroughs. Los Angeles, CA: Semiotext(e).

Mary, B. (1999). Freud et le 'langage d'organe'. In Savoir de la psychose (pp. 17-63). Paris, France: De Boeck.

Mervant, J. (2008). Etre ou ne pas être né d'une femme. Fontanil, France: Alzieu.

Michaud, H. (2011). Les revenants de la mémoire. In Freud et Shakespeare (pp. 3233). Paris, France: PUF.

Minkowski, E. (1927). La schizophrénie. Paris, France: Payot.

Milligan S., \& Antrobus, J. (1970). The bedsitting room. Totton, UK: Hobbs

Mottram E. (1977) William Burroughs, The algebra of need. London, UK: Marion Boyars.

Murphy, T. (1997). Wising up the marks: The amodern William Burroughs. Berkley, CA: University of California Press.

Nuttal, A. D. (1988). Hamlet: Conversations with the Dead. Proceedings of the British Academy, LXXIV, 53-69.

Postel, J., \& Allen D. F. (1994). La psychiatrie. Paris, France: Larousse.

Taibbi, M. (20170). Insane clown president. London, UK: W. H. Allen.

Valenstein, E. S. (1968). Great and desperate cures New York, NY: Basic Books.

Wilson, J. D. (1995). What happens in Hamlet. Cambridge, UK: Cambridge University Press. (Original work published 1935) 